\title{
ANALISIS HASIL BELAJAR PESERTA DIKLAT TEKNIS SUBSTANTIF GURU PEMBINA OLIMPIADE IPA PADA MADRASAH TSANAWIYAH
}

\author{
Oleh: Dermawati \\ Widyaiswara Ahli Utama \\ Pusdiklat Tenaga Teknis Pendidikan dan Keagamaan \\ Email: dermawatinazar@gmail.com
}

\begin{abstract}
ABSTRAK
Peserta didik di Madrasah Tsanawiyah dapat bersaing di OSN, maka guru-guru yang mengajar mereka dan membimbing untuk persiapan OSN haruslah mempunyai kompetensi yang maksimal. Tujuan penelitian untuk menganalisis hasil belajar yang dicapai oleh peserta Diklat Teknis Subtantif Guru Pembina Olimpiade IPA pada Madrasah Tsanawiyah setelah mengikuti proses pembelajaran. Penelitian ini menggunakan metode deskriptif kualitatif dengan responden berjumlah 30 orang. Data penelitian berupa nilai pretest untuk mengukur kemampuan awal peserta diklat dan nilai post test merupakan hasil belajar peserta diklat, serta hasil wawancara tentang kemampuan awal peserta terhadap materi olimpiade, srategi pembelajaran, penilaian terhadap narasumber, manfaat yang diperoleh peserta diklat, dan rencana tindak lanjut dengan menggunakan instrumen wawancara. Data dianalisis secara deskriptif kualitatif. Penelitian ini mengungkapkan bahwa kemampuan awal peserta diklat masih rendah yaitu nilai 46 , kemampuan peserta setelah mengikuti diklat meningkat dengan rata-rata nilai 67 , hasil belajar dari post test Biologi paling tinggi diperoleh guru Biologi yaitu 68 sedangkan guru Fisika dan kimia, penguasaan terhadap materi biologi sama-sama nilai 60, hasil belajar dari post test Biologi paling tinggi diperoleh guru Biologi yaitu 68 sedangkan guru Fisika dan kimia, hasil belajar materi biologi samasama 60, hasil belajar dari soal post test Fisika paling tinggi diperoleh guru kimia yaitu 55 sedangkan guru Fisika 50 dan guru Biologi 51, strategi pembelajaran yang digunakan narasumber cukup memuaskan, dan diklat bermanfaat menambah pengetahuan, disiplin, keterampilan, dan wawasan peserta diklat tentang olimpiade serta bisa bertukar pikiran tentang cara membimbing peserta didik berprestasi di tingkat nasional.
\end{abstract}

Kata Kunci: Hasil belajar, Pembina olimpiade, IPA

\section{ABSTRACT}

Students at Madrasah Tsanawiyah can compete in OSN, so teachers who teach them and guide for the preparation of OSN must have maximum 
competence. The objective of the research is to analyze the learning result achieved by the participants of Technical Substantive Teachers of the Olympic Teachers of Science at Madrasah Tsanawiyah after following the learning process. This research uses qualitative descriptive method with 30 respondents. The data in the research is pretest value to measure the initial ability of the training participants and the post test score is the result of the learning of the training participants, and the interview result about the participants' initial ability to the Olympic material, learning strategy, assessment to the resource, the benefit obtained by the training participants and the follow using interview instruments. Data were analyzed descriptively qualitative. The conclusion of this study is the initial ability of the training participants is still low that is the value of 46, the ability of participants after attending the training increased by an average of 67, the result of learning from post test Biology is the highest obtained by the teacher Biology is 68 while the teacher of Physics and chemistry, mastery of biological materials both the value of 60, the learning outcomes of the post test Biology is the highest obtained by the teacher Biology is 68 while the physics and chemistry teacher, the result of learning biology materials are 60, the result of learning from the post test problem The highest physics is obtained by the chemistry teacher 55 while the teacher Physics 50 and teachers Biology 51, the learning strategies used by the resource persons are quite satisfactory, and the training is useful to increase the knowledge, discipline, skills, and knowledge of the participants about the Olympics and to exchange ideas on how to guide outstanding learners at the national level.

\section{Keywords: Learning outcomes, olympics coach, Science}

\section{PENDAHULUAN}


limpiade Sains Nasional dalah ajang berkompetisi dalam bidang sains bagi para peserta diklat pada jenjang SD, SMP, dan SMA di Indonesia. Peserta didik yang mengikuti Olimpiade Sains Nasional adalah peserta didik yang telah lolos seleksi tingkat kabupaten dan provinsi dan adalah peserta didik terbaik dari provinsinya masingmasing

Pelaksanaan Olimpiade Sains Nasional ini didasarkan pada kesuksesan Indonesia sebagai tuan rumah Olimpiade Fisika Internasional (IPhO - International Physics Olympiad) yang diselenggarakan di Bali pada tahun 2002.

Olimpiade Sains Nasional diadakan sekali dalam satu tahun di kota yang berbeda-beda. Kegiatan ini merupakan salah satu bagian dari rangkaian seleksi untuk mendapatkan peserta diklatsiswi terbaik dari seluruh Indonesia yang akan dibimbing lebih lanjut 
oleh tim bidang kompetisi masingmasing dan akan diikutsertakan pada olimpiade-olimpiade tingkat internasional.

Sementara itu, Direktur Jenderal Pendidikan Dasar dan Menengah (Dikdasmen) Hamid Muhammad mengatakan, penyelenggaraan OSN juga dilakukan dalam rangka pembinaan dan pengembangan bakat, minat, dan prestasi peserta didik.

Menteri Pendidikan dan Kebudayaan (Mendikbud) Muhadjir Effendy yang membuka Olimpiade Sains Nasional (OSN) ke-16 di Kota Pekanbaru, Riau, pada Senin (3/7/2017). OSN tahun ini diselenggarakan dari tanggal 2 Juli 2017 hingga 8 Juli 2017, menyatakan penyelenggaraan OSN ini merupakan bagian dari pengembangan bakat dan prestasi peserta diklat di bidang sains atau ilmu pengetahuan. Selain itu, ia juga mengemukakan bahwa kompetisi sains seperti OSN ini dapat memperkuat karakter peserta didik.

Lebih lanjut Muhajir juga menerangkan bahwa sains atau ilmu pengetahuan sangat dibutuhkan dalam kehidupan berbangsa, bermasyarakat, dan bernegara. Kompetisi sains seperti OSN, diyakini dapat menguatkan karakter peserta didik. Kerja keras, tekun, teliti, dan jujur menjadi keniscayaan jika ingin menjadi ilmuwan hebat,
Muhadjir berharap peserta didik yang berprestasi dalam kompetisi ini bisa memiliki kebanggaan bukan karena mampu mengalahkan lawannya saja. Semangat kompetisi diniatkan untuk kemajuan bangsa. Diselenggarakannya OSN yang bertujuan untuk membina karakter peserta didik agar berintegritas, jujur, pekerja keras, menghargai prestasi, tangguh, dan cinta tanah air.

Agar peserta didik yang bersekolah di Madrasah Tsanawiyah dapat bersaing di OSN, maka guruguru yang mengajar mereka dan membimbing untuk persiapan OSN haruslah mempunyai kompetensi yang maksimal. Maka dari itu guruguru tersebut haruslah mengikuti pendidikan dan pelatihan (diklat) supaya mempunyai wawasan yang luas tentang materi dan strategi OSN.

Pusdiklat Tenaga Teknis Pendidikan dan Keagamaan melaksanakan Diklat Teknis Substantif Guru Pembina Olimpiade IPA bagi Madrasah untuk mewujudkan guru yang kompeten sebagai pembina OSN.

Guru Pembina OSN IPA akan kompeten apabila melakukan proses pembelajaran dalam diklat yang menurut Sugihartono, dkk, (2007: 81) adalah upaya yang dilakukan dengan sengaja oleh pendidikuntuk menyampaikanilmu pengetahuan, mengorganisasi dan 
menciptakan sistem, lingkungan, dengan berbagai metode sehingga peserta diklat dapat melakukan kegiatan pembelajaran secara efektif dan efisien serta dengan hasil optimal.

Hasil belajar yang merupakan outcome dari kegiatan pembelajaran adalah kemampuankemampuan yang dimiliki peserta diklat setelah ia menerima pengalaman belajarnya (Nana Sudjana. 2011: 22). Sedangkan menurut Wina Sanjaya (2009: 13), hasil belajar berkaitan dengan pencapaian dalam memperoleh kemampuan sesuai dengan tujuan khusus yang direncanakan. Tugas utama guru dalam kegiatan ini adalah merancang instrumen yang dapat mengumpulkan data tentang keberhasilan peserta diklat tujuan pembelajaran.

Horward Kingsley dalam Nana Sudjana (2006: 22) membagi tiga macam hasil belajar, yakni keterampilan dan kebiasaan, pengetahuan dan pengertian, sikap dan cita-cita. Gagne dalam (Nana Sudjana, 2006: 22) membagi lima kategori hasil belajar, yakni informasi verbal, keterampilan intelektual, strategi kognitif, sikap, dan keterampilan motoris. Sedangkan dalam sistem pendidikan nasional rumusan tujuan pendidikan, menggunakan klasifikasi hasil belajar menurut Benyamin Bloom yang secara garis besar membaginya menjadi 3 (tiga ranah), yaitu ranah kognitif, ranah afektif, dan ranah psikomotoris.

Menurut Mimin Haryati (2007: 39), penilaian pada aspek afektif dapat dilakukan dengan menggunakan angket/kuesioner, inventori dan pengamatan (observasi).

Hasil belajar merupakan tolak ukur keberhasilan kegiatan belajar mengajar. Hasil belajar dikatakan sebagai hasil akhir dari proses belajar mengajar serta merupakan perwujudan dari kemampuan diri yang optimal setelah menerima pelajaran. Nana Sudjana (2011: 22) juga menyatakan hasil belajar memuat kemampuan yang dimiliki peserta diklat setelah ia menerima pengalaman belajar. Dan Sudijono $(2012$, 32) mengungkapkan hasil belajar merupakan sebuah tindakan evaluasi yang dapat mengungkap aspek proses berpikir (cognitive domain) juga dapat mengungkap aspek kejiwaan lainnya, yaitu aspek nilai atau sikap (affective domain) dan aspek keterampilan (psychomotor domain) yang melekat pada diri setiap individu peserta didik.

Djamarah dan Zain (2013, 2017) menyatakan bahwa setiap proses belajar mengajar selalu menghasilkan hasil belajar dan sampai tingkat mana prestasi (hasil) belajar yang dicapai. Hal ini menggambarkan bahwa yang dapat menjadi fokus bagi pendidik adalah bagaimana mengelola 
pembelajaran sehingga dapat mencapai tingkat hasil belajar yang diinginkan.

Keller(2010,3) mengungkapkan bahwa motivasi adalah motivasi secara umum mengacu pada keinginan atau hasrat seseorang, apa yang menjadi pilihan untuk dilakukannya dan terhadap apa dia memutuskan komitmennya. Ini artinya dalam belajar peserta diklat yang memiliki motivasi akan berkomitmen dalam melakukan kegiatan belajarnya sampai dia memperoleh tujuan belajar yang diinginkannya.

Hasil belajar yang baik akan didapatkan peserta diklat apabila dalam proses pembelajaran termotivasi yang menurut Uno (2014, 23) motivasi belajar secara lebih spesifik merupakan dorongan internal dan eksternal pada peserta diklatpeserta diklat yang sedang belajar untuk mengadakan perubahan tingkah laku, pada umumnya dengan beberapa indikator atau unsur yang mendukung.

Dorongan yang ada dalam diri peserta diklat guru pembina Olimpiade ini akan menyertai dari awal kegiatan belajarnya sampai peserta diklat tersebut merasa cukup untuk mencapai tujuan belajarnya. Dorongan motivasi tersebut akan sangat mempengaruhi bagaimana peserta diklat tersebut mampu belajar dengan baik. Ini artinya melalui motivasi belajar setiap peserta diklat dapat mengalami peningkatan seperti bekerja dengan lebih efektif dan efisien, mengalami peningkatan dalam ketertarikan dalam proses pembelajaran dan mencapai potensi-potensinya secara lebih baik.

Guru-guru yang mengikuti diklat adalah guru-guru IPA di Madrasah Tsanawiyah Perwakilan Provinsi seluruh Indonesia. II mu Pengetahuan Alam (IPA) berkaitan dengan cara mencari tahu tentang alam secara sistematis, sehingga IPA bukan hanya penguasaan kumpulan pengetahuan yang berupa fakta-fakta, konsepkonsep, atau prinsip-prinsip saja tetapi juga merupakan suatu proses penemuan. Pendidikan IPA diharapkan dapat menjadi wahana bagi peserta didik untuk mempelajari diri sendiri dan alam sekitar, serta prospek pengembangan lebih lanjut dalam menerapkannya di dalam kehidupan sehari-hari. Proses pembelajaran menekankan pada pemberian pengalaman langsung untuk mengembangkan kompetensi agar menjelajahi dan memahami alam sekitar secara ilmiah. Pendidikan IPA diarahkan untuk inkuiri dan berbuat sehingga dapat membantu peserta diklat untuk memperoleh pemahaman yang lebih mendalam tentang alam sekitar. 
Pembelajaran adalah upaya untuk membelajarkan peserta didik (Muhaimin, 2002:183).Danmenurut Dimyati dan Mujiono (1999: 157), pembelajaran merupakan proses yang diselenggarakan oleh guru untuk membelajarkan peserta didik dalam belajar bagaimana memperoleh dan memproses pengetahuan, ketrampilan dan sikap. Sedangkan pembelajaran IPA adalah proses interaksi yang dilakukan guru dan peserta diklat dalam mengkaji penguasaan kumpulan pengetahuan yang berupa fakta-fakta, konsepkonsep, atau prinsip-prinsip dan suatu proses penemuan.

Tujuan dari penelitian ini adalah menganalisis hasil belajar yang dicapai oleh peserta Diklat Teknis Subtantif Guru Pembina Olimpiade IPA bagi Madrasah Tsanawiyah setelah mengikuti proses pembelajaran.

\section{METODE PENELITIAN}

Metode penelitian yang peneliti gunakan adalah deskriptif kualitatif dengan responden berjumlah 30 orang peserta Diklat Substantif Guru Pembina Olimpiade IPA pada Madrasah Tsanawiyah Angkatan III yang dilaksanakan tanggal 4 14 September 2017 di Pusdiklat Tenaga Teknis Pendidikan dan Keagamaan.

Data yang digunakan adalah nilai pretest untuk mengukur kemampuan awal peserta diklat dan nilai post test yang merupakan hasil belajar peserta diklat selama mengikuti proses pembelajaran selama 10 hari (100 jam). Juga data tentang penilaian peserta diklat tentang kemampuan awal peserta terhadap materi olimpiade, srategi pembelajaran yang digunakan narasumber, penilaian terhadap narasumber, manfaat yang diperoleh peserta diklat, dan rencana tindak lanjut dengan menggunakan instrumen wawancara. Data dianalisis secara deskriptif kualitatif.

\section{TEMUAN DAN PEMBAHASAN}

\section{Temuan}

Data yang diperoleh dari penelitian ini ada 2 macam yaitu data hasil pretest dan post test serta data hasil wawancara dengan instrumen wawancara tertulis yang diisi oleh 30 peserta dengan jawaban terbuka.

a. Hasil pretest dan post test

Hasil pretest dapat dilihat pada tabel di bawah ini

Tabel 1. Rekapitulasi Hasil Prestest Peserta Diklat Teknis Substantif Pembina Olimpiade IPA pada MTs 


\begin{tabular}{|c|c|c|}
\hline No. & Nilai & Jumlah \\
\hline 1. & $0-10$ & 0 \\
\hline 2. & $11-20$ & 0 \\
\hline 3. & $21-30$ & 2 \\
\hline 4. & $31-40$ & 8 \\
\hline 5. & $41-50$ & 9 \\
\hline 6. & $51-60$ & 9 \\
\hline 7. & $61-70$ & 2 \\
\hline 8. & $71-80$ & 0 \\
\hline 9. & $81-90$ & 0 \\
\hline 10. & $91-100$ & 0 \\
\hline \multicolumn{2}{|c|}{ Rata-rata kelas } & 46 \\
\hline
\end{tabular}

Dari tabel 1 dapat dijelaskan bahwa peserta diklat yang mendapat nilai antara 21-30 berjumlah 2 orang; nilai antara 3140 berjumlah 8 orang; nilai 41-50 berjumlah 9 orang; nilai antara 5160 berjumlah 9 orang; dan yang mendapat nilai $61-70$ berjumlah 2 orang dengan rata-rata kelas nilai 46.

Diagram 1. Rekapitulasi Hasil Prestest Peserta Diklat Teknis Substantif Pembina Olimpiade IPA pada MTs

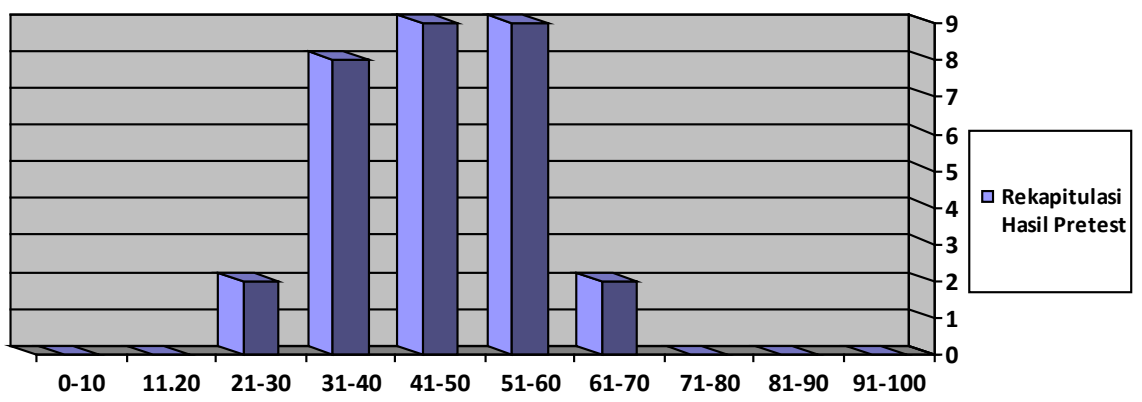

Dari diagram 1 di atas memperlihatkan bahwa nilai pretest peserta diklat masih berkisar antara 21-70, dan nilai yang paling banyak adalah antara 41-60.

Tabel 2. Rekapitulasi Hasil Post test Peserta Diklat Teknis Substantif Pembina Olimpiade IPA pada MTs

\begin{tabular}{|c|c|c|}
\hline No. & Nilai & Jumlah \\
\hline 1. & $0-10$ & 0 \\
\hline 2. & $11-20$ & 0 \\
\hline 3. & $21-30$ & 0 \\
\hline 4. & $31-40$ & 0 \\
\hline 5. & $41-50$ & 1 \\
\hline
\end{tabular}

\begin{tabular}{|c|c|c|}
\hline 6. & $51-60$ & 7 \\
\hline 7. & $61-70$ & 10 \\
\hline 8. & $71-80$ & 8 \\
\hline 9. & $81-90$ & 4 \\
\hline 10. & $91-100$ & 0 \\
\hline \multicolumn{2}{|c|}{ Rata-rata kelas } & 67 \\
\hline
\end{tabular}


Hasil post test dapat dijelaskan seperti data yang terangkum pada tabel 2 yaitu, yang mendapat nilai 41-50 berjumlah 1 orang; nilai 51-60 berjumlah 7 orang; nilai $61-70$ berjumlah 10 orang; nilai $71-80$ berjumlah 8 orang; nilai 81-90 berjumlah 4 orang; dan rata-rata kelas adalah 67.

Diagram 2. Rekapitulasi Hasil Post test Peserta Diklat Teknis Substantif Pembina Olimpiade IPA pada MTs

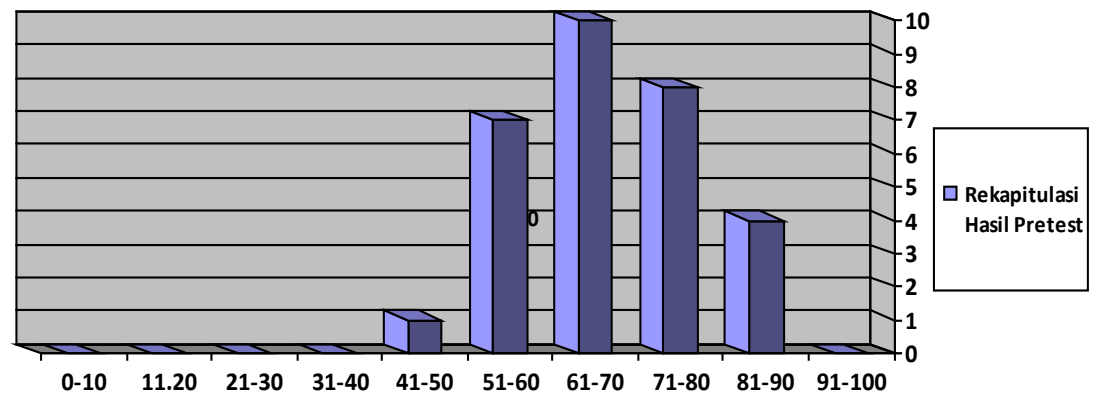

Peserta diklat Teknis Substantif Pembina Olimpiade IPA pada MTs yang berjumlah 30 orang terdiri dari guru mata pelajaran Biologi berjumlah 13 orang, guru mata pelajaran Kimia berjumlah 6 orang, dan guru mata pelajaran Fisika berjumlah 11 orang. Soal pretest dan post test berjumlah 40 buah soal, yaitu 25 soal biologi dan 15 soal fisika. Untuk melihat penguasaan materi olimpiade yang terdiri dari materi biologi dan fisika untuk masing-masing guru mata pelajaran maka didapatkan data seperti di bawah ini.
Tabel 3. Persentase Penguasaan Soal Post test Peserta Diklat Teknis Substantif Pembina Olimpiade IPA pada MTs.

\begin{tabular}{|l|c|c|}
\hline \multirow{2}{*}{ Guru } & \multicolumn{2}{|c|}{ Jenis soal } \\
\cline { 2 - 3 } & Biologi & Fisika \\
\hline Biologi & $68 \%$ & $48 \%$ \\
\hline Kimia & $60 \%$ & $52 \%$ \\
\hline Fisika & $60 \%$ & $50 \%$ \\
\hline
\end{tabular}

Tabel 3 menjelaskan bahwa guru Biologi penguasaan materi biologinya $68 \%$ sedangkan materi fisika 48\%; guru Kimia penguasaan materi biologi $60 \%$ dan materi fisika $52 \%$; dan guru Fisika penguasaan materi biologi $60 \%$ dan materi fisika $50 \%$. 
Diagram 3. Persentase Penguasaan Soal Post test Peserta Diklat Teknis Substantif Pembina Olimpiade IPA pada MTs

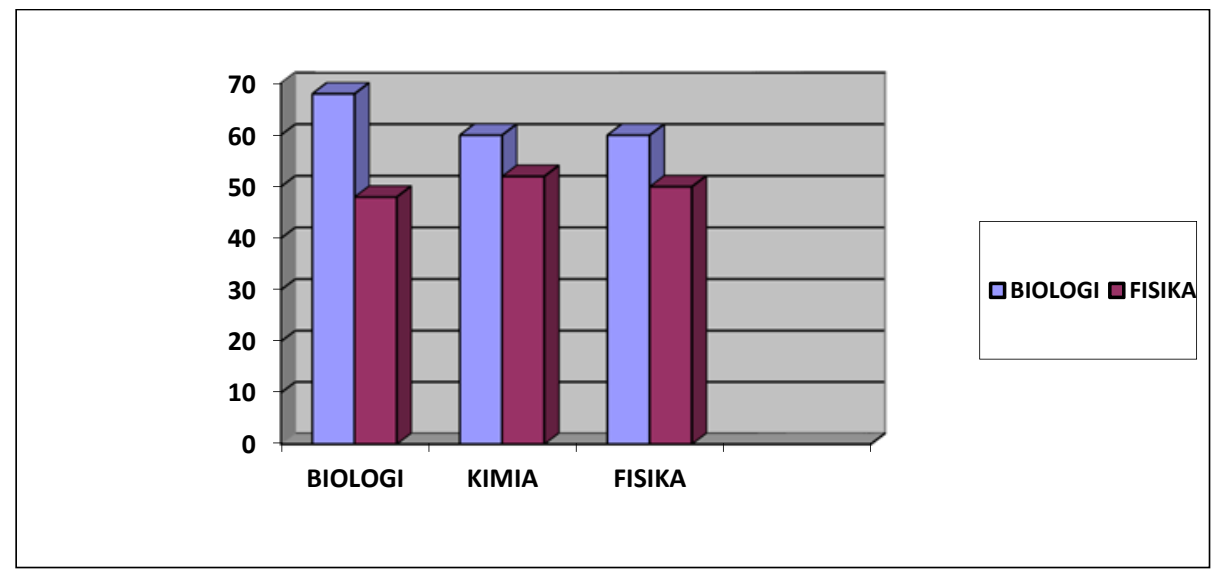

Tabel 4. Analisis Hasil Post test Guru Biologi untuk Soal Biologi dan Fisika

\begin{tabular}{|c|c|c|c|c|}
\hline \multirow{2}{*}{ No. } & \multicolumn{2}{|c|}{ Jenis Soal } & \multicolumn{2}{c|}{ Jenis Soal } \\
\cline { 2 - 5 } & Biologi & $\%$ & Fisika & $\%$ \\
\hline 1. & 16,0 & $64 \%$ & 6,0 & $40 \%$ \\
\hline 2. & 21,0 & $84 \%$ & 10,0 & $67 \%$ \\
\hline 3. & 18,0 & $72 \%$ & 9,0 & $60 \%$ \\
\hline 4. & 21,0 & $84 \%$ & 9,0 & $60 \%$ \\
\hline 5. & 20,0 & $80 \%$ & 9,0 & $60 \%$ \\
\hline 6. & 15,0 & $60 \%$ & 6,0 & $40 \%$ \\
\hline 7. & 15,0 & $60 \%$ & 6,0 & $40 \%$ \\
\hline 8. & 17,0 & $68 \%$ & 11,0 & $73 \%$ \\
\hline 9. & 15,0 & $60 \%$ & 6,0 & $40 \%$ \\
\hline 10. & 13,0 & $52 \%$ & 6,0 & $40 \%$ \\
\hline 11. & 18,0 & $72 \%$ & 6,0 & $40 \%$ \\
\hline 12. & 16,0 & $64 \%$ & 10,0 & $67 \%$ \\
\hline 13. & 15,0 & $60 \%$ & 6,0 & $40 \%$ \\
\hline Rata-rata & 16,9 & $68 \%$ & 7,7 & $51 \%$ \\
\hline
\end{tabular}

Dari tabel 4 terlihat kemampuan 13 orang peserta diklat yang merupakan guru mata pelajaran biologi di tempat tugas masing-masing dalam menjawab soal-soal materi biologi maupun fisika. Adapaun hasilnya antara lain untuk materi biologi rata-rata 16,9 (68\%) dari 25 soal dan materi fisika rata-rata 7,7 dari 15 soal (51\%) 
Diagram 4. Analisis Hasil Post test Guru Biologi untuk Soal Biologi dan Fisika



Tabel 5. Analisis Hasil Post test Guru Kimia untuk Soal Biologi dan Fisika

\begin{tabular}{|c|c|c|c|c|}
\hline \multirow{2}{*}{ No. } & \multicolumn{2}{|c|}{ Jenis Soal } & \multicolumn{2}{c|}{ Jenis Soal } \\
\cline { 2 - 5 } & Biologi & $\%$ & Fisika & $\%$ \\
\hline 1. & 16,0 & $64 \%$ & 9,0 & $60 \%$ \\
\hline 2. & 22,0 & $88 \%$ & 11,0 & $73 \%$ \\
\hline 3. & 19,0 & $76 \%$ & 6,0 & $40 \%$ \\
\hline 4. & 9,0 & $36 \%$ & 7,0 & $47 \%$ \\
\hline 5. & 15,0 & $60 \%$ & 10,0 & $67 \%$ \\
\hline 6. & 8,0 & $32 \%$ & 7,0 & $47 \%$ \\
\hline Rata-rata & 14,8 & $59 \%$ & 8,3 & $55 \%$ \\
\hline
\end{tabular}

Dari tabel 5 terlihat kemampuan 6 orang peserta diklat yang merupakan guru mata pelajaran kimia di tempat tugas masing-masing dalam menjawab soal-soal materi biologi maupun fisika. Adapaun hasilnya antara lain untuk materi biologi rata-rata 14,8 (59\%) dari 25 soal dan materi fisika rata-rata 8,3 dari 15 soal (55\%)

Tabel 6. Analisis Hasil Post test Guru Fisika untuk Soal Biologi dan Fisika

\begin{tabular}{|c|c|c|c|c|}
\hline \multirow{2}{*}{ No. } & \multicolumn{2}{|c|}{ Jenis Soal } & \multicolumn{2}{c|}{ Jenis Soal } \\
\cline { 2 - 5 } & Biologi & $\%$ & Fisika & $\%$ \\
\hline & 18,0 & $72 \%$ & 9,0 & $60 \%$ \\
\hline & 12,0 & $48 \%$ & 5,0 & $33 \%$ \\
\hline
\end{tabular}




\begin{tabular}{|c|c|c|c|c|}
\hline & 18,0 & $72 \%$ & 9,0 & $60 \%$ \\
\hline & 19,0 & $76 \%$ & 7,0 & $47 \%$ \\
\hline & 6,0 & $24 \%$ & 7,0 & $47 \%$ \\
\hline & 20,0 & $80 \%$ & 10,0 & $67 \%$ \\
\hline & 13,0 & $52 \%$ & 6,0 & $40 \%$ \\
\hline & 14,0 & $56 \%$ & 7,0 & $47 \%$ \\
\hline & 17,0 & $68 \%$ & 8,0 & $53 \%$ \\
\hline & 8,0 & $32 \%$ & 8,0 & $53 \%$ \\
\hline & 12,0 & $48 \%$ & 6,0 & $40 \%$ \\
\hline & 14,3 & $57 \%$ & 7,5 & $50 \%$ \\
\hline
\end{tabular}

Dari tabel 6 terlihat kemampuan 11 orang peserta diklat yang merupakan guru mata pelajaran fisika di tempat tugas masing-masing dalam menjawab soal-soal materi biologi maupun fisika. Adapaun hasilnya antara lain untuk materi biologi rata-rata 14,3 (57\%) dari 25 soal dan materi fisika rata-rata 7,5 dari 15 soal ( $50 \%)$

\section{b. Hasil wawancara}

Wawancara yang dilakukan pada semua peserta diklat dengan memberikan instrumen wawancara terbuka, menanyakan tentang kemampuan awal peserta diklat terhadap materi olimpiade, Strategi pembelajaran yang digunakan narasumber, penilaian terhadap narasumber, manfaat yang diperoleh peserta diklat, dan rencana tindak lanjut.

Hasil wawancara tertulis tersebut antara lain:
1) Kemampuan awal terhadap materi olimpiade

Kemampuan peserta diklat sebelum diklat materi terasa sulit. Bagi guru Fisika yang pada awalnya belum tahu konsep dasar ilmu fisika menjadi paham konsep dasarnya. Sedangkan guru biologi, ketika materi biologi mereka mudah memahami, tetapi untuk Fisika peserta diklat kewalahan karena mereka sehari-hari dalam tugas di sekolah tidak mengajar materi tersebut. Sebaliknya guru biologi ketika menerima materi fisikan juga kewalahan karena basic mereka adalah biologi dan ketika mengajar Fisika dalam pembimbingan KSM dan OSN sangat minim serta kurang terprogram. Baik buru biologi, fisika, dan kimia merasakan aktu sangat kurang dan ilmu mereka selama ini masih sangat minim sehingga diklat ini menjadi hal yang tidak terlupakan.

Pada awal mengajar mereka memberikan materi kurang dalam, dengan diklat membantu 
memahami materi yang dipahami selama ini. Mendapat pengalaman baru tentang fisika dan biologi. Dan mereka merasa waktu yang ada sangat terbatas. Pada umumnya bagi peserta diklat guru fisika merasakan materi fisika agak susah tapi setelah diklat banyak yang mereka selama ini belum paham menjadi paham.Mereka merasakan pengetahuan bertambah, dan ilmu yang di dapat di diklat sudah mencukupi untuk menuju olimpiade.

2) Strategi pembelajaran yang digunakan narasumber

Materi yang diberikan oleh narasumber cukup memuaskan, sesuai dengan materi olimpiade, namun perlu tambahan waktu, praktikum dan pembahasan soal-soali, dan alat dan media pembelajaran kurang memadai. Secara umum penyampaian sudah bagus karena masingmasing pemateri berbeda cara penyampaiannya, walaupun ada yang suaranya datar dan caranya biasa-biasa saja.

Peserta lebih mengharapkan strategi penyampaian dari narasumber menggunakan triktrik membahas soal daripada pendalaman materi. Secara umum strategi pembelajaran cukup baik, namun karena waktu diklat cukup panjang dan peserta lelah maka narasumber diharapkan bisa lebih memecahkan suasana dengan ice breaking yang menarik, sehingga dapat dicontoh dan diterapkan di daerah.

3) Penilaian terhadap narasumber

Semua narasumber sudah menguasai materi. Penguasaan materi sudah sangat bagus dan diatas rata-rata, sikap narsum sangat baik, interaktif dan kooperatif, sudah mumpuni karena sesuai dengan bidang yang diampu materi, terutama narasumber fisika penguasaan materinya sangat bagus. Penguatan yang diberikan narasumber cukup baik, hanya ada beberapa yang masing ngambang dan ragu-ragu.

4) Manfaat yang diperoleh peserta diklat

Hasil diklat ini dirasakan peserta sangat menambah pengetahuan dan keterampilan, wawasan tentang olimpiade serta bisa bertukar pikiran tentang cara membimbing peserta diklat sehingga berprestasi di tingkat nasional. Memberikan motivasi dalam membina olimpiade agar anak didik menjadi ilmuwan, mendapat materi baru, referensi baru dan pengalaman baru. Peserta diklat juga belajar disiplin, membangkitkan semangat untuk membimbing KSM dan OSN di MTs, dan mengenal teman-teman dari berbagai daerah. Mereka punya keinginan yang tinggi untuk menguasai soal-soal olimpiade dan mengoleksi dan mempelajari buku-buku IPA yang lebih hebat 
agar tercipta generasi yang hebat dan semakin percaya diri.

5) Rencana tindak lanjut

Peserta diklat membuat rencana tindak lanjut antara lain:

a) Membimbing peserta diklat secara terprogram

b) Berkerja sama dengan teman sejawat

c) Membuat modul tentang materi dan soal-soal olimpiade

d) Mengikutkan peserta diklat untuk setiap ajang olimpiade

e) Untuk pribadi belajar lebih giat lagi

f) Mencari peserta diklat yang mau dibina dan membina dengan ikhlas

g) Lebih menekuni dan mendalami strategi dalam menyelesaikan soal

h) Mengantar peserta diklat ke KSM tingkat Nasional dengan medalai emas, lulus UN IPA dengan nilai 00

i) Menyeleksi peserta diklat yang akan dibina untuk olimpiade

j) Membuat inovasi dan kreasi dalam mengajar di kelas supaya lebih disenangi dan tidak membosankan

k) Melapor kepada Kepala Madrasah dan membagi ilmu dengan teman sejawat

I) Mengimbaskan hasil diklat ke MGMP IPA tingkat Kabupaten.

m) Lebih banyak belajar membahas soal dan membuat target untuk peserta diklat saya.

n) Bersama peserta diklatsiswi membuat alat peraga/ praktikum

o) Mencari literatur yang keren

p) Menghasilkan medali yang lebih lagi

q) Menjadi guru yang mujadid

r) Mengembangkan media pembelajaran IPA yang inovatif yang dapat mendukung kegiatan pembelajaran di sekolah

s) Semakin bergairah membina olimpiade

t) Menggunakan referensi minimal SMA.

\section{Pembahasan}

Dari hasil pretest peserta diklat Teknis Substantif Pembina Olimpiade IPA pada MTs yang ditampilkan pada tabel 1 dan diagram 1, nilai peserta masih berkisar pada 31-60 dan ratarata kelas masih rendah yaitu 46. Melihat hasil pretest tersebut, dapat dianalisis bahwa kemampuan peserta sebagai pembina olimpiade masih sangat minim yaitu kurang dari $50 \%$.

Pada tabel 2 dan diagram 2 , setelah mengikuti diklat nilai post test mereka sudah banyak yang berkisar pada 51-80. Artinya hasil belajar mereka sudah lebih meningkat dengan rata-rata 67 . 
Peningkatan hasil belajar mereka adalah 21 yaitu dari nilai semula 46 menjadi 67.

Persentase penguasaan soal post test peserta diklat Teknis Substantif Pembina Olimpiade IPA pada MTs (tabel 3 dan diagram 3) rata-rata hampir sama. Dilihat dari hasil belajar materi biologi, yang tertinggi adalah guru biologi yaitu 68. Sedangkan guru kimia dan guru fisika hasil belajar materi biologi sama-sama 60. Dan untuk hasil belajar fisikanya, yang paling tinggi penguasaan soal adalah guru kimia yaitu 50. Nilai ini masing minim untuk kriteria mereka sebagai pembina olimpiade. Harusnya nilai untuk soal fisika didapatkan oleh guru fisika, tetapi dari data di atas justru yang mendapatkan nilai yang paling tinggi adalah guru kimia.

Wawancara yang dilakukan pada semua peserta diklat dengan memberikan instrumen wawancara terbuka, menanyakan tentang kemampuan awal peserta diklat terhadap materi olimpiade, strategi pembelajaran yang digunakan narasumber, penilaian terhadap narasumber, manfaat yang diperoleh peserta diklat, dan rencana tindak lanjut.

Dari hasil wawancara dapat dianalisis bahwa kemampuan awal terhadap materi olimpiade masih minim dan mereka sulit memahami materi baik untuk materi biologi maupun fisika. Setelah mengikuti diklat bagi yang belum tahu konsep dasar ilmu fisika maupun biologi menjadi paham konsep dasarnya. Guru biologi kesulitan menerima materi fisika, dan sebaliknya guru fisika juga kesulitan menerima materi biologi apalagi guru kimia yang basic dasar keilmuannya adalah kimia. Selama ini mereka memberikan materi kurang dalam, dengan diklat membantu memahami materi yang dipahami selama ini belum tuntas mereka pahami.

Strategi pembelajaran yang digunakan narasumber cukup memuaskan, sesuai dengan materi olimpiade, namun perlu tambahan waktu, praktikum dan pembahasan soal-soal. Tetapi peserta lebih mengharapkan strategi penyampaian dari narasumber menggunakan trik-trik membahas soal daripada pendalaman materi dengan ice breaking yang menarik agarsuasana pembelajaran menjadi bergairah dan menyenangkan.

Alat dan media pembelajaran kurang memadai. Penggunaan media pembelajaran sangat menunjang untuk pemahaman materi yang lebih bagus. Untuk melengkapi kekurangan alat dan media pembelajaran ini maka peserta diklat melaksanakan observasi lapangan ke laboratorium biologi Universitas Negeri Jakarta. Di lokasi observasi lapangan mereka dalami dalami adalah profil laboratorium FMIPA UNJ, demonstrasi penggunaan 
DNA untuk identifikasi organisme, demonstrasi kultur mikroorganisme, sedang kunjungan ke laboratorium fisika dipelajari tentang profil laboratorium FMIPA UNJ, alat-alat pengukuran, alat-alat gerak, daya dan fluida, alat-alat cahaya dan optik, alat-alat magnet dan kalor. Dengan observasi lapangan ini peserta cukup puas, karena banyak alat dan media yang mereka belum ketahui jenisnya, kegunaannya dan cara menggunakannya.

Semua narasumber penguasaan materi sudah sangat bagus yang diampu sesuai dengan bidang masing-masing dan diatas rata-rata. Sikap narasumber sangat baik, interaktif dan kooperatif.. Penguatan yang diberikan narasumber cukup baik, walaupun ada beberapa yang masing ngambang dan ragu-ragu.

Hasil diklat ini dirasakan peserta sangat menambah pengetahuan dan keterampilan, wawasan tentang olimpiade serta bisa bertukar pikiran tentang cara membimbing peserta didik sehingga berprestasi di tingkat nasional. Memberikan motivasi dalam membina olimpiade agar anak didik menjadi ilmuwan, mendapat materi baru, referensi baru dan pengalaman baru. Peserta diklat juga belajar disiplin, membangkitkan semangat untuk membimbing KSM dan OSN di MTs, dan mengenal teman-teman dari berbagai daerah. Mereka punya keinginan yang tinggi untuk menguasai soal-soal olimpiade dan mengoleksi dan mempelajari buku-buku IPA yang lebih hebat agar tercipta generasi yang hebat dan semakin percaya diri.

Dengan diklat peserta mengetahui bahwa tugas pembina antara lain: menjaring peserta diklat berpotensi yang akan dibina, membuat jadwal pembinaan, melakukan pembinaan secara kontinue, aktif menambah wawasan keilmuan IPA. Sedangkan strategi pembelajaran yang harus dilakukan adalah harus mempunyai sikap "jangan bertindak sebagai guru", memposisikan diri sebagai pembina/pelatih, berperan sebagai motivator dan fasilitator, memberikan masukan dan umpan balik ke peserta diklat, mendorong peserta diklat untuk aktif mencari materi sendiri dari berbagai sumber (internet, buku, dII), mendorong terjadinya diskusi antara peserta diklat dan pembina mengenai materi yang sedang dibahas. Materi yang diajarkan antara lain tidak langsung memberikan soal sulit yang membuat peserta diklat "stres", dimulai dari pengetahuan yang dimiliki peserta diklat (sesuai kurikulum), lebih menekankan pada pemahaman konsep yang menjadi dasar untuk menemukan pengetahuan yang baru, diberikan secara berjenjang.

Untuk

model-model 
pembelajaran peserta diklat juga dapat masukan dari model pembelajaran yang ditampilkan oleh narasumber. Peserta dapat menerapkan model yang baik serta cocok ketika mereka kembali kedaerah masing-masing untuk membina peserta didik mereka dalam olimpiade. Model pembelajaran yang bisa mereka terapkan antara lain peserta diklat diajari terlebih dahulu materi penghantar kemudian mereka diberi soal dan setelah selesai diberikan lagi materi penghantar dan diberikan soal lagi, peserta diklat diberikan masalah, kemudian mereka dibimbing satu-satu dalam mengerjakan, yang cepat selesai akan segera mendapat tambahan soal sampai selesai, peserta diklat diberikan paket soal kemudian diberikan waktu \pm 1 jam untuk mengerjakan kemudian baru di bahas.

Kriteria Soal Olimpiade yang harus diterapkan antara lain materi harus sesuai dengan pengetahuan yang dimiliki peserta diklat, dirancang agar peserta diklat tidak mempunyai prosedur khusus untuk mengerjakan, dirancang agar ada proses pemecahan masalah dalam menyelesaikan soalnya. Dan kendala yang dihadapi peserta dalam membuat soal adalah membuat soal yang bermutu yang biasanya membutuhkan waktu yang lama, biasanya pembuat soal hanya membuat soal yang berhubungan dengan aktivitas harian sehingga peserta diklat kurang mendapat wawasan, dan soal-soal yang dihasilkan setiap minggu sedikit.

\section{PENUTUP}

\section{Simpulan}

a. Kemampuan awal peserta diklat sebagai pembina olimpiade masih minim yaitu nilai 46

b. Kemampuan peserta setelah mengikuti diklat meningkat dengan ratarata 67

c. Hasil belajar soal post test Biologi paling tinggi diperoleh guru Biologi yaitu 68 sedangkan guru Fisika dan kimia, penguasaan terhadap materi biologi sama-sama 60.

d. Hasil belajar soal post test Biologi paling tinggi diperoleh guru Biologi yaitu $68 \%$ sedangkan guru Fisika dan kimia, penguasaan terhadap materi biologi sama-sama 60.

e. Hasil belajar soal post test Fisika paling tinggi diperoleh guru kimia yaitu 55 sedangkan guru Fisika 50 dan guru Biologi 51 .

f. Strategi pembelajaran yang digunakan narasumber cukup memuaskan, sesuai dengan materi olimpiade 
g. Diklat menambah pengetahuan, disiplin, keterampilan, dan wawasan peserta diklat tentang olimpiade serta bisa bertukar pikiran tentang cara membimbing peserta didik berprestasi di tingkat nasional.

\section{Rekomendasi}

a. Adanya diklatdiklat lanjutan untuk meningkatkan pemahaman guru terhadap materi IPA. b. Diklat yang dilaksanakan hendaknya dipisahkan antara guru Fisika, Biologi, dan Kimia agar memperoleh materi secara maksimal terkait dengan spesialisasi masing-masing.

c. Waktu diklat ditambah supaya peserta diklat memperoleh kompetensi sebagai pembina olimpiade lebih banyak dan berkualitas.

\section{DAFTAR PUSTAKA}

De Porter, Bobbi dan Hernacki Mike. 1992. Quantum Learning. Membiasakan Belajar Nyaman dan Menyenangkan. Terjemahan oleh Alwiyah Abdurrahman. Bandung: Penerbit Kaifa.

Dimyati dan Mujiono. Belajar dan Pembelajaran. Jakarta: Depdikbud bekerjasama dengan Rineka Cipta, 1999

Djamarah, S.B. \& Zain, B. 2013. Strategi belajar mengajar. Jakarta: PT. Rineka Cipta

Sudijono, A. 2012. Pengantar evaluasi pendidikan. Jakarta: PT. Raja Grafindo Persada

Sujimat, D. Agus. 2000. Penulisan Karya Ilmiah. Makalah disampaikan pada pelatihan penelitian bagi guru SLTP Negeri di Kabupaten Sidoarjo tanggal 19 Oktober 2000 (Tidak diterbitkan). MKKS SLTP Negeri Kabupaten Sidoarjo

https://cakepmuchtar.wordpress.com/2010/10/11/strategi-pembinaanolimpiade/ (Diakses 26 Oktober 2017)

Keller, J. M. 2010. Motivational Design For Learning And Performance The Arcs Model Approach. London: Springer 
Mimin, Haryati. 2007. Model \& Teknik Penilaian Pada Tingkat Satuan Pendidikan. Jakarta: Gaung Persada Press

Muhaimin. 2002. Paradigma Pendidikan Islam Upaya Mengefektifkan Pendidikan Agama Islam di Sekolah. Bandung: PT Remaja Rosda Karya

Nana Sudjana. 2011. Penilaian Hasil Proses Belajar Mengajar. Bandung: Remaja Rosdakarya

Peraturan Menteri Pendidikan Nasional No 22 Tahun 2006 tentang Standar Kompetensi dan Kompetensi Dasar Sekolah Menengah Pertama SMP)/Madrasah Tsanawiyah (MTs)

Suparno. 2000. Langkah-langkah Penulisan Artikel Ilmiah dalam Saukah, Ali dan Waseso, M.G. 2000. Menulis Artikel untuk Jurnal Ilmiah. Malang: UM Press.

Sugihartono, et. al. 2007. Psikologi Pendidikan. Yogyakarta: UNY Press.

Uno, H. B. 2014. Teori Motivasi \& Pengukurannya Analisis Di Bidang Pendidikan. Jakarta: PT. Bumi Aksara.

UNESA. 2000. Pedoman Penulisan Artikel Jurnal. Surabaya: Lembaga Penelitian Universitas Negeri Surabaya.

Wahab, Abdul dan Lestari, Lies Amin. 1999. Menulis Karya Ilmiah. Surabaya: Airlangga University Press.

Wina Sanjaya. 2009. Strategi Pembelajaran Berorientasi Standar Proses Pendidikan. Jakarta: Kencana Prenada Media Group.

Winardi, Gunawan. 2002. Panduan Mempersiapkan Tulisan Ilmiah. Bandung: Akatiga 